\title{
Studies on the health impact of Agrimonia procera in piglets
}

\author{
Tobias Gräber ${ }^{1}$, Holger Kluge ${ }^{1}$, Sebastian Granica², Gert Horn ${ }^{3}$, Corinna Brandsch ${ }^{1}$ and Gabriele I Stangl ${ }^{\text {* }}$
}

\begin{abstract}
Background: The weaning period is critical for stress-related diseases and infections. Currently, large amounts of therapeutic antimicrobials are used to treat infections in the livestock production, especially in piglets. Phytogenic feed additives could provide a useful alternative. We hypothesize, that components in agrimonia species which have been used successfully in humans to treat gastrointestinal infections could also improve the health of piglets. We investigated the effects of Agrimonia procera (AP) on the growth performance of piglets and cytokine expression in isolated porcine peripheral blood mononuclear cells (PBMC).

Results: Here we show that piglets that received a diet with $0.56 \mathrm{~g} / \mathrm{kg}$ AP for 6 weeks tended to ingest more food $(+5.1 \% ; P<0.10)$, and were characterized by a higher nitrogen retention $(+9.6 \%, P<0.05)$ than the control group without AP treatment. Data from a second experiment reveal that piglets fed a diet with $0.87 \mathrm{~g} / \mathrm{kg}$ AP for 6 weeks had an improved food conversion ratio $(1.46 \pm 0.04)$ compared to those that received none $(1.54 \pm 0.08)$ or $8.7 \mathrm{~g} / \mathrm{kg}$ AP $(1.60 \pm 0.08)$ with their diets $(P<0.001)$. However, the food intake, daily weight gain and dry matter of feces were not affected by the AP treatment.

Treatment of PBMC for 1 and $6 \mathrm{~h}$ with AP extract (APE) reduced the mRNA abundance of tumor necrosis factor (TNF)a in cells challenged with lipopolysaccharides (LPS) but not in cells without LPS stimulation $(P<0.05)$. The lower mRNA expression of TNFa was accompanied by a trend towards a lower release of TNFa from these cells $(P=0.067)$. After the treatment of PBMC with APE for $6 h$, the relative mRNA concentration of interleukin (IL)- $1 \beta$ declined $(P<0.05)$, whereas that of IL-10 remained unchanged. Treatment of LPS-challenged PBMC for $20 \mathrm{~h}$ with varying concentrations of APE did not reveal any effect on cytokine expression and TNFa release.
\end{abstract}

Conclusions: The results indicate that low dosages of AP may improve the growth performance of piglets and seem to exert antiinflammatory effects in porcine immune cells challenged with LPS.

Keywords: Agrimonia procera, Polyphenol, Growth performance, Cytokine expression, Pig, Peripheral blood mononuclear cells

\section{Background}

For many decades it was a common practice to add subtherapeutic amounts of antibiotics to the feed of pigs to control intestinal pathogens and to promote growth. However, the rising incidence of antibiotic-resistant bacterial infections prompted the European Union in 2006 to introduce a ban on growth-promoting antimicrobials (Regulation 1831/2003/EC). Nevertheless, the overall use of therapeutic antimicrobials to treat infections of farm livestock remained high. Throughout the fatting period,

\footnotetext{
* Correspondence: gabriele.stangl@landw.uni-halle.de

${ }^{1}$ Institute of Agricultural and Nutritional Sciences, Martin Luther University Halle-Wittenberg, Von-Danckelmann-Platz 2, 06120 Halle (Saale), Germany Full list of author information is available at the end of the article
}

pigs received antimicrobials on average for 35 days, whereby most of the antimicrobials were administered to young animals [1]. Those data demonstrate that the weaning period is a critical period for stress-related diseases and infections during livestock production [1,2]. Stress factors such as weaning, pathogen exposure and littermate separation may induce reduced food intake, body weight loss and an increased susceptibility to gastrointestinal infections in these animals [3,4]. Botanicals and phytogenic feed additives are discussed as useful alternatives to the therapeutic use of antimicrobials because they are supposed to modulate the immune system and to improve performance of pigs. In practice, mixtures of spices, herbs and oils that contain thymol, 
carvacrol and vanillin were used in piglet production. Among the phytogenic additives, extracts from agrimonia have been reported as eligible candidates that possess antioxidative, anti-inflammatory and antibacterial properties, and exert beneficial effects on lipid metabolism [5-8]. Agrimonia belongs to the family of Rosaceae and is a genus of $12-15$ species of perennial herbaceous flowering plants. The most common species of agrimonia in Europe (Agrimonia eupatoria L. and Agrimonia procera Wallr.) are used in folk medicine traditionally for the treatment of diarrhea, colitis, grumbling appendix, cystitis and wound healing [9-11]. The major bioactive compounds of Agrimonia eupatoria (AE) are polyphenols such as flavonoids, mainly glycosides of luteolin and apigenin, and agrimoniin [12]. Recent data show that extracts from $\mathrm{AE}$ are capable of improving the antioxidative status of broiler chickens [13]. Agrimonia procera (AP) is very similar to AE [14], but seems to have a greater antioxidative capacity [15], and is characterized by a higher yield than the commonly used AE. The effects of AP in piglet nutrition and on cytokine synthesis in challenged porcine immune cells are currently unknown. The first objective of this study was to test the effects of AP on growth performance and diarrhea frequency of weaned piglets in two feeding experiments.

Weaning of piglets is often linked to a transient increase in inflammatory cytokines such as interleukin (IL)-1及, IL6 and tumor necrosis factor (TNF) $\alpha$ [16] which are produced by monocytes and macrophages, respectively. These cytokines stimulate systemic effects of inflammation such as fever, loss of appetite, and mobilization of protein and fat. Conversely, IL-10 prevents excessive TNF $\alpha$ production [17-19]. The second objective of the study was to investigate putative effects of AP on the cytokine profile of lipopolysaccharides (LPS) challenged peripheral blood mononuclear cells (PBMC), isolated from healthy piglets.

\section{Results}

\section{Composition of Agrimonia procera}

One gram dried powder of the AP leaves that was used in experiment 1 contained $1.21 \mathrm{mg}$ quercetin equivalents and $74 \mathrm{mg}$ gallic acid equivalents. The dried powder of AP leaves and stalks which was used in experiment 2 contained $0.43 \mathrm{mg}$ quercetin equivalents and $40 \mathrm{mg}$ gallic acid equivalents per g. Agrimoniin and the luteolin and apigenin glycosides were identified as the main phytochemicals of AP. The AP powder from leaves contained $12.7 \mathrm{mg}$ and the AP powder from leaves and stalks contained $6.38 \mathrm{mg}$ agrimoniin per g of dry mass, respectively.

\section{Animal performance}

During the feeding experiments all piglets remained healthy and did not need any medication. Mean initial and final body weights, daily weight gain, food intake and the food conversion ratio (FCR) are summarized in Tables 1 and 2. In both experiments, the final body weights and the daily weight gain were not influenced by AP (Tables 1 and 2).

In experiment 1 , the food and nitrogen intake tended to be higher in piglets fed the AP diets than in piglets fed the control diet $(P<0.10)$, whereas the FCR and the nitrogen excretion via urine and feces remained unaffected by AP treatment (Table 1). Collectively, piglets treated with AP showed a higher retention of nitrogen than the control piglets (Table 1 ).

In experiment 2, the food intake did not differ between the three groups of piglets, but piglets fed a diet with $0.87 \mathrm{~g} \mathrm{AP} / \mathrm{kg}$ exhibit an improved FCR compared to piglets fed none or $8.7 \mathrm{~g}$ AP per $\mathrm{kg}$ diet (Table 2). The consistency of feces was not different between the three groups of piglets (Table 3). The plasma activities of alanine aminotransferase (ALT) and aspartate aminotransferase (AST), indicative for liver damage, were not different between the AP groups and the control group (Table 4). The total antioxidant capacity of the plasma, analyzed by the Trolox equivalent antioxidant capacity assay, was not different between the three groups of piglets (Table 4).

\section{Cytokine mRNA expression and TNFa release of PBMC in response to AP extract}

PBMC challenged with LPS for 1 and $6 \mathrm{~h}$, respectively, revealed a markedly higher mRNA expression of TNF $\alpha$, IL-1 $\beta$ and IL-10 than non-stimulated PBMC $(\mathrm{P}<0.05)$. The mRNA level of TNF $\alpha$ was highest after $1 \mathrm{~h}$, whereas the mRNA levels of IL-1 $\beta$ and IL-10 where highest after $6 \mathrm{~h}$ of LPS stimulation (Figure 1). In non-stimulated PBMC, AP extract (APE) revealed no significant effect on the mRNA expression of the cytokines (Figure 1). LPS-challenged PBMC treated for 1 and $6 \mathrm{~h}$ with $0.1 \%$ (v/v) of APE revealed a lower TNF $\alpha$ mRNA expression than cells without APE treatment ( $\mathrm{P}<0.05$, Figure $1 \mathrm{~A})$. The mRNA expression of IL- $1 \beta$ was also reduced in response to treatment with $0.1 \%$ of APE, but this effect was only seen after $6 \mathrm{~h}(\mathrm{P}<0.05)$, but not after $1 \mathrm{~h}$. The mRNA expression of the anti-inflammatory IL-10 was not affected by APE (Figure 1).

To test whether the altered TNF $\alpha$ mRNA expression in response to LPS and APE was associated with an altered protein expression and release of TNF $\alpha$, we analyzed the TNF $\alpha$ concentration in the cell media. The incubation media of non-stimulated PBMC was characterized by very low TNF $\alpha$ concentrations (Figure 2). LPS stimulation increased the extracellular TNF $\alpha$ concentration, whereby the increase was much higher after $6 \mathrm{~h}$ than after $1 \mathrm{~h}$ of incubation $(\mathrm{P}<0.05$; Figure 2$)$. Treatment of LPS-challenged PMBC with $0.1 \%$ APE for $1 \mathrm{~h}$ 
Table 1 Performance of weaned piglets fed diets without or with Agrimonia procera

\begin{tabular}{llll}
\hline Parameter & Control & Agrimonia procera $\mathbf{0 . 5 6} \mathbf{~ g / k g )}$ & P-value \\
\hline Initial body weight $(\mathrm{kg})$ & $8.1(0.7)$ & $8.1(0.8)$ & 0.909 \\
Final body weight $(\mathrm{kg})$ & $25.2(2.8)$ & $25.9(3.1)$ & 0.177 \\
Daily weight gain $(\mathrm{g} / \mathrm{d})$ & $407(68)$ & $425(66)$ & 0.148 \\
Food intake $(\mathrm{g} / \mathrm{d})^{1}$ & $594(63)$ & $624(63)$ & 0.088 \\
Food conversion ratio $(\mathrm{kg} / \mathrm{kg})^{1}$ & $1.46(0.11)$ & $1.46(0.11)$ & 0.972 \\
Nitrogen intake $(\mathrm{g} / \mathrm{d})^{2}$ & $14.49(1.33)$ & $15.65(0.32)$ & \\
Nitrogen excretion ${ }^{2}$ & & $3.31(0.46)$ & 0.094 \\
$\quad$ Feces $(\mathrm{g} / \mathrm{d})$ & $2.99(0.53)$ & $2.09(0.37)$ & 0.340 \\
$\quad$ Urine $(\mathrm{g} / \mathrm{d})$ & $2.14(0.34)$ & $10.26(0.51)^{*}$ & 0.839 \\
Retention $(\mathrm{g} / \mathrm{d})^{2}$ & $9.36(0.66)$ & $65.6(4.1)$ & 0.044 \\
Retention $(\%)^{2}$ & $64.8(2.4)$ & 0.712 \\
\hline
\end{tabular}

Mean values (SD), $\mathrm{n}=60$ per group.

${ }^{1}$ Means of two piglets per pen were averaged.

${ }^{2} \mathrm{n}=5$ per group.

*Significantly different from control (Student's $t$ test).

had no effect on the extracellular TNFa concentration. However, PBMC treated with APE for $6 \mathrm{~h}$ tended to release less TNF $\alpha$ into the cell media than those without APE treatment $(\mathrm{P}=0.067)$.

Data from the second in vitro experiment showed that PBMC challenged for $20 \mathrm{~h}$ with LPS had higher mRNA abundances of TNF $\alpha, \quad$ IL-1 $\beta$ and IL-10 than nonstimulated PBMC $(\mathrm{P}<0.05$, Figure 3$)$. Treatment of cells with increasing dosages of APE for $20 \mathrm{~h}$ had no effect on the mRNA expression of these cytokines (Figure 3), and also the extracellular TNF $\alpha$ concentration was not influenced by those treatments (Figure 4).

\section{Discussion}

It is suggested that phytochemicals are attributable to the proposed beneficial health effects of herbal feed additives in livestock. Analyses from the current study show that AP belongs to plants that are rich in flavonoids and polyphenols, especially in agrimoniin which is a major bitter plant polyphenolic compound of AP. By comparison of AP with other agrimonia species, for example those which were used for humans, AP contained less total flavonoids than $\mathrm{AE}$, although the total polyphenols of AP are higher compared to the extracts from flowering aerial parts of other agrimonia species [15]. However, the differences in contents of phytochemicals between agrimonia species and within a defined species could be also caused by differences in the harvest period, the growth conditions and the plant parts that are used for the analysis.

Recent studies have documented that herbal feed additives could improve the performance of piglets, including food intake [20,21]. A trend towards a higher food intake was also seen in the AP treated piglets from experiment 1 , assuming that also herbals such as AP, may stimulate the appetite of piglets. Although such an appetite-stimulating effect of AP was not seen in experiment 2, piglets that were fed a diet with $0.87 \mathrm{~g}$ AP per $\mathrm{kg}$ diet revealed a lower FCR than piglets treated without AP. Both effects of AP on food intake and FCR are desirable and indicative for an improved performance. The fact that piglets that were fed the high AP diet containing $8.7 \mathrm{~g}$ AP per $\mathrm{kg}$ diet revealed a deteriorated FCR compared to that of control piglets suggests a biphasic effect of AP with optimum effects in the low dosage range. Aminotransferase activities in plasma which are

Table 2 Performance of weaned piglets fed two different dosages of Agrimonia procera

\begin{tabular}{lllll}
\hline Parameter & Control & Agrimonia procera (AP) & & High AP (8.7 g/kg) \\
\cline { 3 - 4 } & & Low AP $(\mathbf{0 . 8 7} \mathbf{~ g / k g})$ & $8.6(0.7)$ & P-value \\
\hline Initial body weight $(\mathrm{kg})$ & $8.4(0.6)$ & $8.3(0.8)$ & $23.4(2.5)$ & 0.346 \\
Final body weight $(\mathrm{kg})$ & $23.1(2.9)$ & $24.1(2.0)$ & $352(46)$ & 0.445 \\
Daily weight gain $(\mathrm{g} / \mathrm{d})$ & $349(61)$ & $377(35)$ & $560(58)$ & 0.168 \\
Food intake $(\mathrm{g} / \mathrm{d})$ & $537(79)$ & $551(54)$ & $1.60(0.08)^{\mathrm{a}}$ & 0.524 \\
Food conversion ratio $(\mathrm{kg} / \mathrm{kg})$ & $1.54(0.08)^{\mathrm{b}}$ & $1.46(0.04)^{\mathrm{c}}$ & & $<0.001$ \\
\hline
\end{tabular}

Mean values (SD), $\mathrm{n}=20$ per group.

$a, b, c$ Values not sharing the same superscript are significantly different (Fisher's test). 
Table 3 Feces dry matter of weaned piglets fed two different dosages of Agrimonia procera

\begin{tabular}{llll}
\hline Parameter & Control & & Agrimonia procera (AP) \\
\cline { 4 - 4 } Feces dry matter (\%) & Low AP (0.87 g/kg) & High AP (8.7 g/kg) \\
1. Week & $23.2(6.0)$ & $22.9(4.1)$ & $20.2(7.1)$ \\
2. Week & $25.9(4.1)$ & $26.5(3.8)$ & $24.0(5.2)$ \\
3. Week & $27.1(2.7)$ & $27.4(2.3)$ & $27.0(2.7)$ \\
\hline
\end{tabular}

Mean values (SD), $n=20$ per group.

sensitive markers of possible tissue damage, particularly liver toxicity, do not imply a toxic effect of the high AP diet, because circulating ALT and AST activities were not different between the AP groups and the control group. Weaning is most commonly associated with an increased proliferation of gut microbiota and hypersecretion of bacterial enterotoxins [22]. Non-absorbed dietary phenolics and their metabolites have been assumed to exert significant effects on the intestinal environment by modulation of the microbiota [23,24]. It is possible that the beneficial effect of the low AP diet on FCR and nitrogen retention in our study was caused by beneficial effects on gut microbiota. Antioxidative effects of AP appear to play no role, because AP fed piglets revealed no higher antioxidant capacity of the plasma than the control animals. On the other hand the adverse effect of the high AP diet on FCR could possibly be provoked by the high amounts of tannins such as agrimoniin which are known to deteriorate the digestibility of nutrients, in particular that of protein [25].

Various studies demonstrated the anti-inflammatory potential of agrimonia [26,7]. Although the mechanisms of the antiinflammatory effects of plant extracts have not yet been fully elucidated, recent data show that extracts from $\mathrm{AE}$ were capable of reducing the activity of nuclear factor-kappa-light-chain-enhancer of activated B cells (NF- $\mathrm{KB}$ ) via suppression of its nuclear translocation [27]. It is discussed that polyphenols activate heterodimers of NF-E2-related factors 2/antioxidant responsive element pathway which in turn may modify the NF- $\mathrm{kB}$ activity $[28,29]$. In order to test the anti-inflammatory potential of AP, we used therefore LPS-challenged PBMC from

Table 4 Aminotransferase activities and total antioxidant capacity in plasma of weaned piglets fed two different dosages of Agrimonia procera

\begin{tabular}{llll}
\hline & & \multicolumn{2}{l}{ Agrimonia procera (AP) } \\
\cline { 3 - 4 } Parameter & Control & Low AP $(\mathbf{0 . 8 7} \mathbf{~ g / k g )}$ & High AP $\mathbf{8 . 7} \mathbf{~ g / k g})$ \\
\hline ALT $^{1}(\mathrm{U} / \mathrm{l})$ & $18.7(4.8)$ & $17.3(4.0)$ & $18.1(4.6)$ \\
AST $(\mathrm{U} / \mathrm{l})$ & $40.8(10.3)$ & $41.6(15.3)$ & $46.5(11.0)$ \\
TEAC $(\mu \mathrm{mol} / \mathrm{l})$ & $7.60(0.63)$ & $7.63(1.06)$ & $7.67(0.77)$ \\
\hline
\end{tabular}

Mean values (SD), $n=20$ per group.

${ }^{1}$ ALT: alanine aminotransferase; AST: aspartate aminotransferase; TEAC: Trolox equivalent antioxidant capacity. healthy piglets as inflammation model. LPS are found in the outer membrane of gram-negative bacteria, where they function as endotoxins and elicit strong immune responses. We found that extracts from AP were capable of reducing the mRNA expression of pro-inflammatory cytokines such as TNF $\alpha$ and IL-1 $\beta$ in the LPSchallenged PBMC, without affecting the mRNA expression of the anti-inflammatory IL-10. This means that AP is capable of changing the cytokine profile towards a reduction of the pro-inflammatory response under LPSchallenging conditions. Moreover, the data show a timedependent impact of APE on the mRNA expression of pro-inflammatory cytokines, with strong effects during the first hours, and failing effects after $20 \mathrm{~h}$. Proinflammatory cytokines and their receptors are known to antagonize the anabolic effects of insulin-like growth factor (IGF) 1 by reducing its synthesis and by a reduction of the responsiveness of target tissue to IGF-1 stimulation [30]. Considering the fact that weaningassociated intestinal inflammation [16] is usually linked to adverse effects on nutrient metabolism, growth, and muscle development in pigs [31], a reduction of a severe pro-inflammation state by AP could contribute to reduce acute symptoms of infection and to maintain normal growth conditions. We assume that the phytochemicals of AP are responsible for the down regulation of the proinflammatory cytokines since apigenin and luteolin has been already identified as inhibitors of pro-inflammatory cytokine production in LPS-stimulated PBMC [32], and as factors which reduce the transcriptional activity of NF- $\mathrm{kB}$ in LPS-stimulated primary monocytes [33] and macrophages [34].

\section{Conclusion}

Collectively, the data show that low dosages of AP could provide beneficial effects on feed intake and FCR in piglets. Data from in vitro studies with LPS-challenged PBMC indicate that $\mathrm{AP}$ extracts are capable of reducing the mRNA expression and synthesis of pro-inflammatory cytokines. The actual efficacy of AP to maintain the health of piglets and its potential to reduce the application of antimicrobials has to be investigated under practical animal production conditions. 


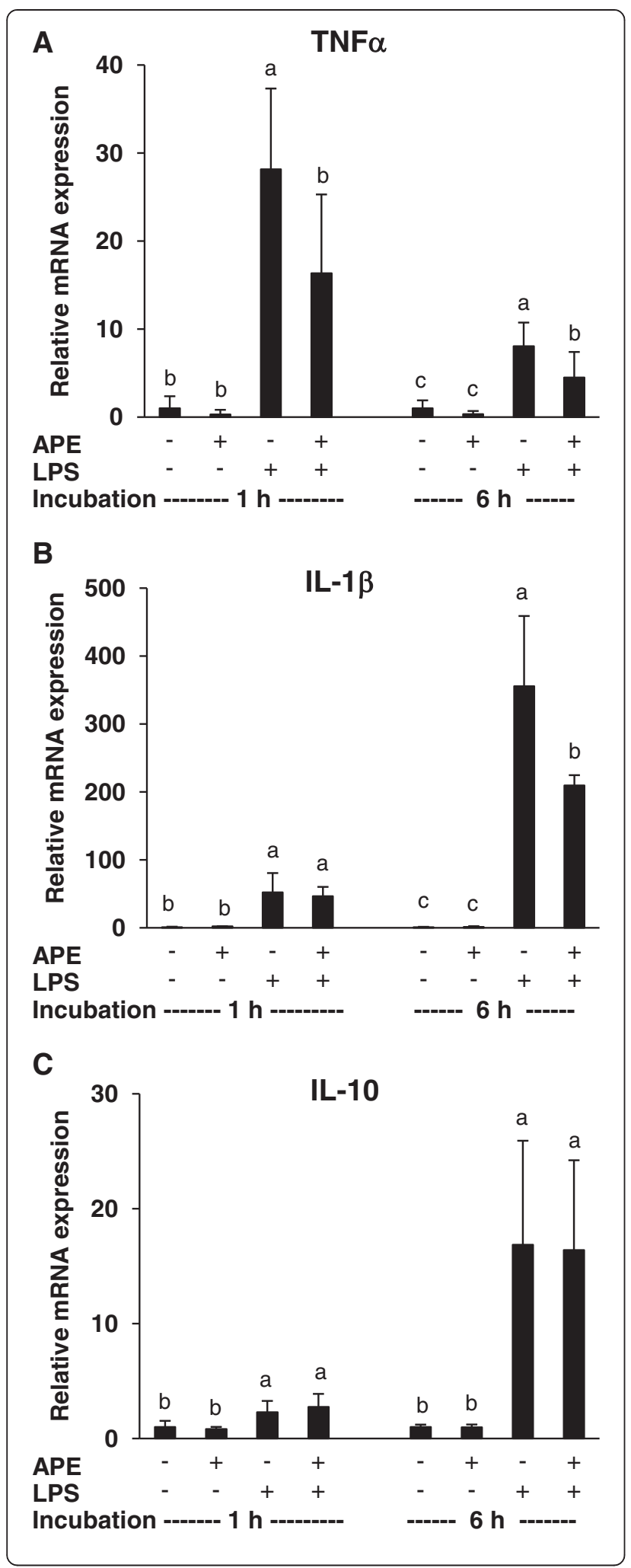

Figure 1 Effects of Agrimonia procera extract (APE) on cytokine mRNA expression by porcine PBMC. Relative mRNA concentrations of TNFa (A), IL-1 $\beta$ (B) and IL-10 (C) were analyzed in non-stimulated and LPS $(1 \mu \mathrm{g} / \mathrm{ml})$-stimulated PBMC $\left(2 \times 10^{6}\right.$ per ml RPMI 1640 medium) treated with 0 or $0.1 \%$ APE for 1 and $6 \mathrm{~h}$, respectively. PBMC were isolated from 4 healthy piglets. mRNA expression was normalized to that of $\beta$-actin. Data represent mean $\pm S D(n=4)$. ${ }^{a}$ b Bars with different superscript letters within an incubation period differ significantly $(P<0.05$, Fisher's test)

\section{Methods}

\section{Animal experiments}

All experimental procedures described were approved by the local Animal Care and Use Committee of the council of Saxony-Anhalt (approval number: 42502 Merbitz$15 \mathrm{MLU}$ ) and were in accordance with German animal welfare legislation. We declare that we adhered to the ARRIVE guidelines (see Additional file 1).

\section{Animals and diets}

Two studies were performed with 120 (experiment 1) and 60 (experiment 2) healthy 4-week old weaned hybrid piglets [(German Landrace $\times$ German Edelschwein $) \times$ Piétrain]. The piglets were purchased from a local breeder. For the first feeding experiment, castrated male and female (1:1) piglets were randomly assigned to 2 groups of 60 each. One group received a basal diet with $0 \mathrm{~g}$ AP per $\mathrm{kg}$ diet (control), the other group received a diet with $0.56 \mathrm{~g}$ AP per $\mathrm{kg}$ diet as finely ground AP leaves (Exsemine GmbH, Zappendorf, Germany). To test whether higher amounts of AP are more effective in

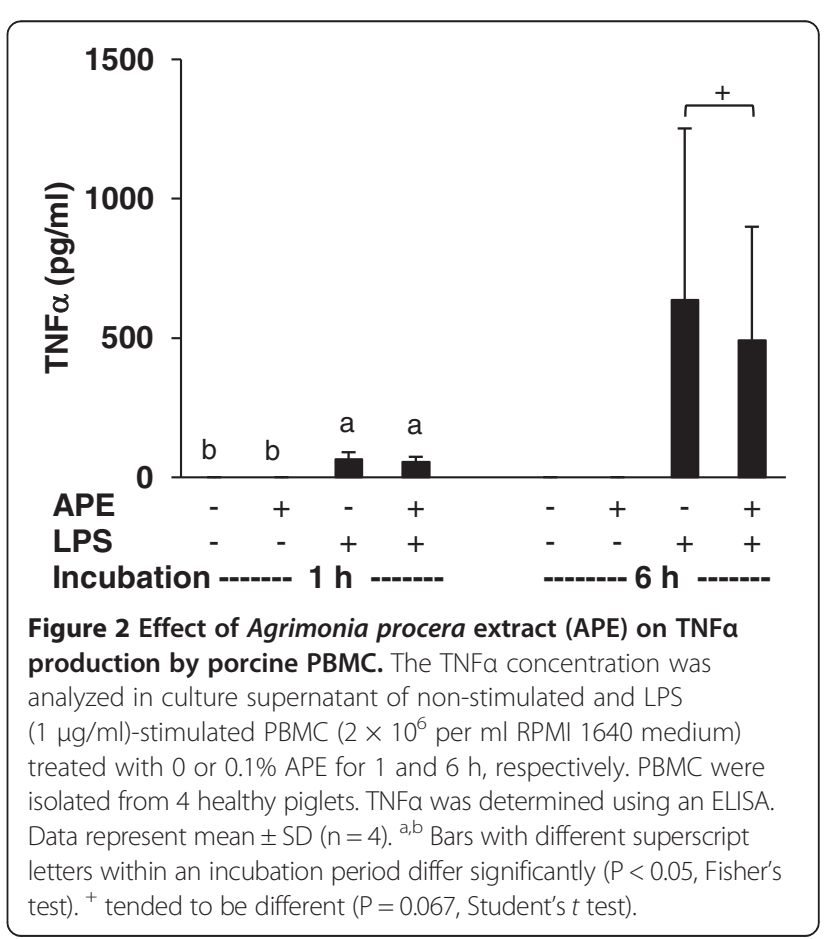



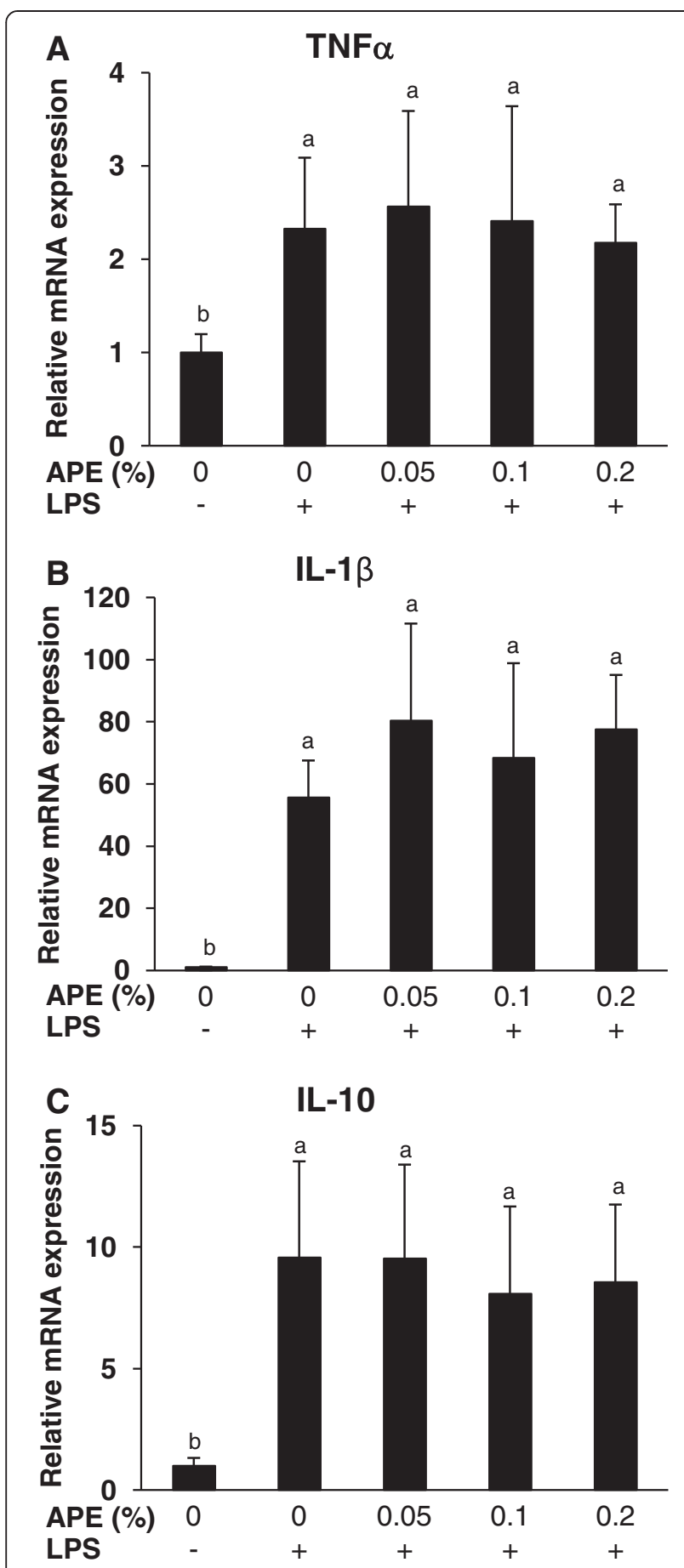

Figure 3 Effect of Agrimonia procera extract (APE) on cytokine mRNA expression by porcine PBMC. Relative mRNA

concentrations of TNFa (A), IL-1 $\beta$ (B) and IL-10 (C) were analyzed in non-stimulated and LPS $(1 \mathrm{\mu g} / \mathrm{ml})$-stimulated PBMC $\left(2 \times 10^{6}\right.$ per $\mathrm{ml}$ RPMI 1640 medium) treated with $0,0.05,0.1$ or $0.2 \%$ APE for $20 \mathrm{~h}$. PBMC were isolated from 6 healthy piglets. The relative mRNA expression was normalized to that of RPPO and SDHA. Data represent mean $\pm S D(n=6)$. ${ }^{a}, b$ Bars with different superscript letters differ significantly $(P<0.05$, Fisher's test).

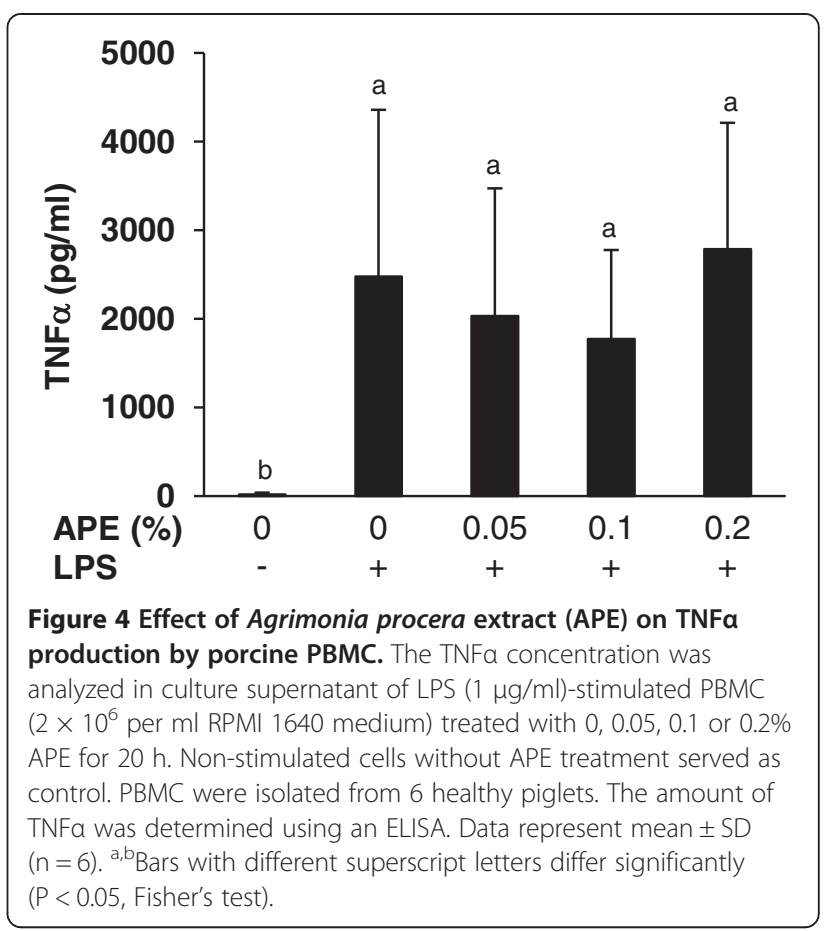

influencing the performance of the piglets, a second feeding experiment was conducted. In this experiment, castrated male and female (1:1) piglets were randomly assigned to 3 groups of 20 each, and either received 0 , 0.87 and $8.7 \mathrm{~g} \mathrm{AP}$ per $\mathrm{kg}$ diet, respectively, with their diet as finely ground AP leaves and stalks. The amounts of AP were chosen to attain an equal concentration of total polyphenol as in experiment 1 ( $35 \mathrm{mg}$ per g AP) in the low AP diet and a 10 times higher concentration (350 mg per g AP) in the high AP diet.

The experimental diets were fed for a total of 6 weeks. In the first two weeks a pre-starter diet served as basal diet and in the following 4 weeks the piglets received standard starter diets (Table 5). The AP powder was added at the expense of the basal diet. The basal diets were formulated to meet the nutrient requirements recommended for piglets [35]. All piglets had free access to food. Water was available ad libitum from a nipple drinker system during the whole experiment. The piglets were housed in flat deck pens (two piglets per pen in experiment 1 and one piglet per pen in experiment 2). All animals were kept in an environmentally controlled facility with a temperature of $29^{\circ} \mathrm{C}$ at the beginning which decreased to $22^{\circ} \mathrm{C}$ at the end of the experiments, relative humidity between $55-60 \%$, and light from $6: 00$ am to 6:00 pm.

Food intake and body weight were recorded weekly. Based on these data, average daily weight gain, daily food intake and FCR (food intake/weight gain) were calculated. At day 28 of the experiment 1, five castrated male piglets per group were transferred to metabolic cages for 
Table 5 Composition of the basal diets ( $\mathrm{g} / \mathrm{kg}$ )

\begin{tabular}{lll}
\hline Ingredients & Pre-starter $^{\mathbf{1}}$ & Starter $^{\mathbf{2}}$ \\
\hline Wheat & 40.0 & 40.0 \\
Barley & 19.45 & 20.0 \\
Maize & 10.0 & 12.0 \\
Soybean meal (48\% crude protein) & 18.0 & 18.42 \\
Whey powder & 5.0 & 2.5 \\
Wheat semolina bran & 3.0 & 3.0 \\
Soybean oil & 2.5 & 2.4 \\
Mono-calcium-phosphate & 0.5 & 0.5 \\
Lysine HCl & 0.68 & 0.55 \\
DL-methionine & 0.27 & 0.2 \\
L-threonine & 0.3 & 0.23 \\
L-tryptophan & 0.08 & 0.06 \\
L-valine & 0.22 & 0.14 \\
Mineral and vitamin premix & & 2.0
\end{tabular}

'based on $13.9 \mathrm{MJ}$ net energy (NE)/kg and standardized ileal digestible amino acids [lysine $12 \mathrm{~g} / \mathrm{kg}$, methionine/cystine $6.83 \mathrm{~g} / \mathrm{kg}$, threonine $7.42 \mathrm{~g} / \mathrm{kg}$, tryptophan $2.4 \mathrm{~g} / \mathrm{kg}$ ]

${ }^{2}$ based on $13.77 \mathrm{MJ} \mathrm{NE} / \mathrm{kg}$ and standardized ileal digestible amino acids [lysine $10.1 \mathrm{~g} / \mathrm{kg}$, methionine/cystine $6.15 \mathrm{~g} / \mathrm{kg}$, threonine $6.59 \mathrm{~g} / \mathrm{kg}$ tryptophan $2.16 \mathrm{~g} / \mathrm{kg}]$.

${ }^{3}$ per $\mathrm{kg}$ premix: calcium $265 \mathrm{~g}$, sodium $60 \mathrm{~g}$, phosphorus $40 \mathrm{~g}$, magnesium $5.5 \mathrm{~g}$, iron $2.85 \mathrm{~g}$, zinc $2.2 \mathrm{~g}$, copper $750 \mathrm{mg}$, manganese $730 \mathrm{mg}$, cobalt $15 \mathrm{mg}$, iodine $10 \mathrm{mg}$, selenium $10 \mathrm{mg}$, vitamin A 1,000,000 IU, vitamin D $100,000 \mathrm{IU}$, nicotinic acid $2.6 \mathrm{~g}$, vitamin E $2 \mathrm{~g}$, pantothenic acid $1.25 \mathrm{~g}$, riboflavin $500 \mathrm{mg}$, pyridoxine $300 \mathrm{mg}$, thiamin $200 \mathrm{mg}$, vitamin K $150 \mathrm{mg}$, folic acid $30 \mathrm{mg}$, vitamin $B_{12} 2 \mathrm{mg}$, biotin $1 \mathrm{mg}$, choline chloride $20 \mathrm{~g}$, flavoring substance $1.5 \mathrm{~g}$.

a total of 5 days to estimate the nitrogen retention. During this period the piglets were fed controlled amounts of the experimental diets twice a day $07: 30 \mathrm{am}$ and 03:00 pm). After a $24 \mathrm{~h}$ adaptation period feces and urine were collected quantitatively. In experiment 2 , the feces consistency was analyzed once a week in the first three weeks of the study by analyzing the dry matter content of the feces. At day 28, blood was collected from the vena jugularis for analysis of plasma aminotransferases and TEAC.

\section{Analysis of the phytochemicals in AP}

For phytochemical analysis, the AP leaves and stalks were crushed and homogenized. The total polyphenol content defined as gallic acid equivalent and the total flavonoid content defined as quercetin equivalent were analyzed according to [15] by using Folin-Ciocalteu phenol reagent and aluminum chloride hexahydrate (both Sigma-Aldrich, Sternheim, Germany), respectively.

The individual compounds of AP were determined in cooperation with the Department of Pharmacognosy and Molecular Basis of Phytotherapy, Medical University of Warsaw. The plant compounds were extracted with hot deionized water and analyzed with UHPLC-DAD-MS as described previously [12]. The HPLC analyses were performed using an Ultimate 3000 series system (Dionex, Idtsein, Germany), and a UV-vis in the range of 200$450 \mathrm{~nm}$ and MS spectra.

\section{Nitrogen analyses}

Nitrogen concentrations of diets, feces and urine were analyzed by the Kjeltec system (Kjeltec 2300, Foss, Hamburg, Germany). The dry matter content of the diets and feces was analyzed by drying of the samples at $105^{\circ} \mathrm{C}$ for $4 \mathrm{~h}$.

\section{Analysis of plasma aminotransferases and the antioxidant capacity}

To monitor any adverse or toxic effects of the AP diets, we analyzed the plasma activities of alanine aminotransferase (ALT) and aspartate aminotransferase (AST) that are sensitive markers of possible tissue damage. Both enzymes were photometrically determined by use of commercial test kits (DiaSys Diagnostic Systems GmbH, Holzheim, Germany).

To reveal the antioxidant capacity of plasma in response to the AP diets, a Trolox equivalent antioxidant capacity (TEAC) assay was used. TEAC was measured according the method of Wang et al. [36] and Mueller et al. [37]. The method is based on the suppression of the absorbance of the 2,20-azino-bis (3-ethylbenzothiazoline-6-sulphonic acid (ABTS) radical formation by antioxidants in the test samples. The reaction mixture contained PBS buffer, ABTS reagent $(0.15 \mathrm{mM}), \mathrm{H}_{2} \mathrm{O}_{2}(0.1 \mathrm{mM})$ and metmyoglobin $(2.52 \mathrm{mM})$. The absorbance was measured at $600 \mathrm{~nm}$ for $15 \mathrm{~min}$ at $20^{\circ} \mathrm{C}$. Sample values were calculated using a standard curve and were expressed as $\mu \mathrm{mol} / \mathrm{l}$.

\section{In vitro experiments}

\section{Isolation of the PBMC}

To investigate the effects of AP on the expression of cytokines, porcine PBMC were obtained from healthy weaned piglets (mean body weight $18 \mathrm{~kg}$ ). For the first experiment, 4 piglets were used as donors, and for the second experiment, PBMC of 6 piglets were included. The cells were isolated from peripheral blood drawn from the anterior vena cava by density gradient separation with Histopaque ${ }^{\circ} 1077$ (Sigma-Aldrich) according to the manufacturer's protocol. In brief, whole EDTAblood was layered (1:1) onto Histopaque. After centrifugation at $400 \times \mathrm{g}$ for $30 \mathrm{~min}$ at room temperature, the mononuclear cells at the interface were harvested, washed three times with phosphate buffered saline solution and re-suspended in RPMI 1640 medium (Life Technologies, Darmstadt, Germany) supplemented with $5 \%$ heat-inactivated fetal bovine serum (FBS, Life Technologies). 


\section{Cell treatments}

For the incubation experiments, an ethanolic extract of AP was prepared by dissolving $200 \mathrm{mg}$ of AP powder in $1 \mathrm{ml}$ of ethanol (99\% pure). The mixture was incubated for $30 \mathrm{~min}$ at $75^{\circ} \mathrm{C}$. The insoluble constituents were removed by centrifugation at 2,500 $\times$ g for $5 \mathrm{~min}$ and the resulting supernatant was stored at $-20^{\circ} \mathrm{C}$ until further use.

In both experiments, the PBMC were seeded into 24multiwell plates at a density of $2 \times 10^{6}$ cells per ml RPMI 1640 medium. In the first cell experiment, the PBMC were incubated in RPMI 1640 medium without or with $1 \mu \mathrm{g} / \mathrm{ml}$ LPS (Escherichia coli 0127:B8, Sigma-Aldrich), and with 0 or $0.1 \%(\mathrm{v} / \mathrm{v})$ of APE for 1 and $6 \mathrm{~h}$, respectively, at $37^{\circ} \mathrm{C}$ and $5 \% \mathrm{CO}_{2}$. In the second cell experiment, LPS $(1 \mu \mathrm{g} / \mathrm{ml})-$ challenged PBMC were treated with $0,0.05,0.1$ or $0.2 \%$ of APE for $20 \mathrm{~h}$. The longer incubation time in experiment 2 was used to allow enough time for the synthesis of TNF $\alpha$ and to get significant TNF $\alpha$ amount to be performed. Cells without LPS stimulation and 0\% APE in the incubation medium served as controls. APE was added to the culture medium in a maximal volume $(<0.4 \%)$ and the same volume of ethanol as the solvent was added to the medium of the control cells. Subsequent to the treatment PBMC were transferred into tubes, harvested by centrifugation at $900 \times$ $\mathrm{g}$ for $2 \mathrm{~min}$ and used for analysis of mRNA concentrations of TNF $\alpha$, IL- $1 \beta$ and IL-10 by real-time detection RT-PCR. The culture supernatant was centrifuged a second time at $13,000 \times \mathrm{g}$ for $5 \mathrm{~min}$ to remove cell debris and was stored at $-20^{\circ} \mathrm{C}$ until quantification of secreted TNF $\alpha$ by means of an ELISA.

\section{Real-time RT-PCR analysis}

Total RNA was isolated from PBMC using peqGOLD TriFast $^{\text {тM }}$ (Peqlab, Erlangen, Germany) according to the manufacturer's protocol. RNA concentration and purity were estimated from the optical density at 260 and $280 \mathrm{~nm}$, respectively. $0.4 \mu \mathrm{g}$ of total RNA was subjected to cDNA synthesis at $42^{\circ} \mathrm{C}$ for $60 \mathrm{~min}$ using M-MuLV Reverse Transcriptase (MBI Fermentas, St. Leon-Rot, Germany) and oligo dT18-primer (Eurofins MWG Operon, Ebersberg, Germany). For determination of mRNA expression levels real-time detection PCR using the Rotorgene 6000 system (Corbett Research, Mortlake, Australia) was applied. Real-time PCR was performed by using $1.25 \mathrm{U}$ GoTaq Flexi DNA polymerase (Promega, Mannheim, Germany), $500 \mu \mathrm{M}$ dNTP (Ares Bioscience, Cologne, Germany), SYBR ${ }^{\bullet}$ Green I (Sigma, Taufkirchen, Germany) and 26.7 pmol of the specific primers (Eurofins MWG Operon). Each PCR cycle comprised denaturation for $20 \mathrm{~s}$ at $95^{\circ} \mathrm{C}$, annealing for $35 \mathrm{~s}$ at primer-specific temperature $\left(57-64^{\circ} \mathrm{C}\right)$ and elongation for $55 \mathrm{~s}$ at $72^{\circ} \mathrm{C}$. For determination of the mRNA concentration, threshold cycle $\left(\mathrm{C}_{\mathrm{T}}\right)$ and amplification efficiency were obtained from each
Table 6 Characteristics of the primers used in RT-PCR analysis and PCR product sizes

\begin{tabular}{|c|c|c|c|}
\hline Gene & $\begin{array}{l}\text { Forward primer (from 5' to } 3^{\prime} \text { ) } \\
\text { Reverse primer (from 5'to } 3^{\prime} \text { ) }\end{array}$ & $\begin{array}{l}\text { Product } \\
\text { size (bp) }\end{array}$ & $\begin{array}{l}\text { NCBI GenBank } \\
\text { number }\end{array}$ \\
\hline \multirow[t]{2}{*}{$\beta$-actin } & GACATCCGCAAGGACCTCTA & 205 & DQ_845171.1 \\
\hline & ACATCTGCTGGAAGGTGGAC & & \\
\hline \multirow[t]{2}{*}{$\mathrm{SDHA}^{1}$} & CTAGCCCCCGTCGCAAAGG & 380 & DQ_402993 \\
\hline & AGTTTGCCCCCAGGCGGTTG & & \\
\hline \multirow[t]{2}{*}{ RPPO } & CAACCCTGAAGTGCTTGACA & 204 & NM_001098598.1 \\
\hline & GCCTTGACCTITTCAGCAAG & & \\
\hline \multirow[t]{2}{*}{ TNFa } & AACCCTCTGGCCCAAGGA & 57 & NM_214022.1 \\
\hline & GGCGACGGGCTTATCTGA & & \\
\hline \multirow[t]{2}{*}{ IL-1 $\beta$} & AAAGGGGACTTGAAGAGAG & 286 & NM_001005149.1 \\
\hline & CTGCTTGAGAGGTGCTGATGT & & \\
\hline \multirow[t]{2}{*}{ IL-10 } & GCATCCACTTCCCAACCA & 446 & NM_214041.1 \\
\hline & СТTССТСАTCTTCATCGTCAT & & \\
\hline
\end{tabular}

${ }^{1} \mathrm{SDHA}$, succinate dehydrogenase complex subunit A; RPP0, ribosomal phosphoprotein large PO subunit; TNF, tumor necrosis factor; IL, interleukin.

amplification curve using the RotorGene 1.7 software (Corbett Research). Calculation of the relative mRNA concentration was made using the method previously described by Pfaffl [38]. The amplification data of single genes were normalized to the expression of stable housekeeping genes. In the first study the most stable reference gene was $\beta$-actin; in the second study, succinate dehydrogenase complex subunit A (SDHA) and ribosomal phosphoprotein large PO subunit (RPP0) were used as reference genes because both genes had proved to be the most stable genes. The relative mRNA concentrations were expressed as fold-changes relative to the control. The primer sequences and characteristics are shown in Table 6.

\section{Analysis of TNFa in cell culture supernatant}

The concentration of TNF $\alpha$ in the supernatant was determined by a porcine TNF $\alpha$ ELISA kit (R\&D Systems, Abingdon, UK) according to the manufacturer's instructions.

\section{Statistical analysis}

Statistical analysis was carried out by using one way ANOVA (Minitab, Version 13, State College, PA, USA). In the case of significant F-values $(\mathrm{P}<0.05)$ comparisons of more than two groups were done using the Fisher's test. The Student's $t$ test was used for the comparison of two groups. Means were considered significantly different at $\mathrm{P}$ $<0.05$. Data represent means \pm standard deviation (SD).

\section{Additional file}

Additional file 1: The ARRIVE Guidelines Checklist. 


\section{Abbreviations}

AE: Agrimonia eupatoria; AP: Agrimonia procera; APE: Agrimonia procera extract; ALT: Alanine aminotransferase; AST: Aspartate aminotransferase; DM: Dry matter; FCR: Food conversion ratio; IGF: Insulin-like growth factor; IKB: Inhibitor protein kappa B; IL: Interleukin; LPS: Lipopolysaccharide; NF-KB: Nuclear factor-kappaB; PBMC: Peripheral blood mononuclear cells; RPPO: Ribosomal phosphoprotein large PO subunit; SDHA: Succinate dehydrogenase complex subunit A; TNF: Tumor necrosis factor; TEAC: Trolox equivalent antioxidant capacity.

\section{Competing interests}

The authors declare that they have no competing interests.

\section{Authors' contributions}

$\mathrm{CB}, \mathrm{GIS}, \mathrm{HK}$ and TG designed the study and interpreted the data; $\mathrm{GH}$ cultivated and processed the plant material; $\mathrm{CB}, \mathrm{HK}$ and TG conducted the experiment; SG and TG conducted the analyses of AP; TG performed statistical analyses; $\mathrm{CB}, \mathrm{GIS}$ and TG wrote the paper with input from all authors. All authors read and approved the final manuscript.

\section{Acknowledgements}

This work was supported by The Deutsche Bundesstiftung Umwelt (DBU), reference number 27074-34

\section{Author details}

'Institute of Agricultural and Nutritional Sciences, Martin Luther University Halle-Wittenberg, Von-Danckelmann-Platz 2, 06120 Halle (Saale), Germany. ${ }^{2}$ Department of Pharmacognosy and Molecular Basis of Phytotherapy, Medical University of Warsaw, Faculty of Pharmacy, Banacha St. 1, $02-097$ Warsaw, Poland. ${ }^{3}$ Exsemine GmbH, Am Wehr 4, Salzatal 06198, Germany.

Received: 13 February 2014 Revised: 25 April 2014

Accepted: 29 August 2014

Published: 9 September 2014

\section{References}

1. MARAN-2008: Monitoring of antimicrobial resistance and antibiotic usage in animals in the Netherlands in 2008. http://www.wageningenur.nl/ upload_mm/8/1/3/8dba0d30-4efb-42e7-a66c-f7bfd151bdf6_MARAN2008.pdf.

2. Merle R, Hajek P, Käsbohrer A, Hegger-Gravenhorst C, Mollenhauer Y, Robanus M, Ungemach F, Kreienbrock L: Monitoring of antibiotic consumption in livestock: a German feasibility study. Prev Vet Med 2012, 104:34-43.

3. Madec F, Bridoux N, Bounaix S, Jestin A: Measurement of digestive disorders in the piglet at weaning and related risk factors. Prev Vet Med 1998, 35:53-72.

4. Kick AR: Effects of Stress on the adaptive immune system in pigs. MSc thesis. Raleigh: North Carolina State University, Physiology Department; 2010.

5. Swanston-Flatt SK, Day C, Bailey CJ, Flatt PR: Traditional plant treatments for diabetes. Studies in normal and streptozotocin diabetic mice. Diabetologia 1990, 33:462-464.

6. Copland A, Nahar L, Tomlinson CTM, Hamilton V, Middleton M, Kumarasamy $Y$, Sarker SD: Antibacterial and free radical scavenging activity of the seeds of Agrimonia eupatoria. Fitoterapia 2003, 74:133-135.

7. Bae H, Kim H, Shin M, Lee H, Yin CS, Ra J, Kim J: Inhibitory effect of Agrimoniae Herba on lipopolysaccharide-induced nitric oxide and proinflammatory cytokine production in BV2 microglial cells. Neurol Res 2010, 32(Suppl 1):53-57.

8. Ivanova D, Vankova D, Nashar M: Agrimonia eupatoria tea consumption in relation to markers of inflammation, oxidative status and lipid metabolism in healthy subjects. Arch Physiol Biochem 2013, 119:32-37.

9. Ivanova D, Gerova D, Chervenkov T, Yankova T: Polyphenols and antioxidant capacity of Bulgarian medicinal plants. J Ethnopharmacol 2005, 96:145-150.

10. Ivanova D, Tasinov O, Vankova D, Kiselova-Kaneva Y: Antioxidative potential of Agrimonia eupatoria L. Science \& Technol 2011, 1:20-24.

11. Wichtl H: Teedroge und Phytopharmaka: Ein Handbuch für die Praxis auf wissenschaftlicher Grundlage. Stuttgart: Wissenschaftliche Verlagsgesellschaft mbH; 1997.

12. Granica S, Krupa K, Kłębowska A, Kiss AK: Development and validation of HPLC-DAD-CAD-MS3 method for qualitative and quantitative standardization of polyphenols in Agrimoniae eupatoriae herba (Ph. Eur). J Pharma Biomed Analysis 2013, 86:112-122

13. Petrovic V, Marcincak S, Popelka P, Simkova J, Martonova M, Buleca J, Marcincakova D, Tuckova M, Molnar L, Kovac G: The effect of supplementation of clove and agrimony or clove and lemon balm on growth performance, antioxidant status and selected indices of lipid profile of broiler chickens. J Anim Physiol Anim Nutr 2012, 96:970-977.

14. Venskutonis P, Škèmaitè M, Sivik B: Assessment of radical scavenging capacity of Agrimonia extracts isolated by supercritical carbon dioxide. J Supercritical Fluids 2008, 45:231-237.

15. Kubinova R, Jankovska D, Bauerova V: Antioxidant and a-glucosidase inhibition activities and polyphenol content of five species of Agrimonia genus. Acta Fytotechnica et Zootechnica 2012, 2:38-41.

16. Pié $S$, Lallès JP, Blazy F, Laffitte J, Sève B, Oswald IP: Weaning is associated with an upregulation of expression of inflammatory cytokines in the intestine of piglets. J Nutr 2004, 134:641-647.

17. Spurlock ME: Regulation of metabolism and growth during immune challenge: an overview of cytokine function. J Anim Sci 1997, 75:1773-1783.

18. Dinarello CA: Proinflammatory cytokines. Chest 2000, 118:503-508.

19. Kim K, Kim D, Kim S, Jung E, Kang J, Jeung E, Yang M: Trans-10, cis-12conjugated linoleic acid attenuates tumor necrosis factor-a production by lipopolysaccharide-stimulated porcine peripheral blood mononuclear cells through induction of interleukin-10. Cytokine 2011, 56:224-230.

20. Costa LB, Luciano FB, Miyada VS, Gois FD: Review article: Herbal extracts and organic acids as natural feed additives in pig diets. S Afr J Anim Sci 2013, 43:181-193.

21. Yan $L$, Meng $Q$, Kim I: The effect of an herb extract mixture on growth performance, nutrient digestibility, blood characteristics and fecal noxious gas content in growing pigs. Livestock Sci 2011, 141:143-147.

22. Gallois M, Rothkötter HJ, Bailey M, Stokes CR, Oswald IP: Natural alternatives to in-feed antibiotics in pig production: can immunomodulators play a role? Animal 2009, 3:1644-1661.

23. Chung KT, Cheng IW, Johnson MG: Are tannins a double-edged sword in biology and health? Trends Food Sci Tech 1998, 9:168-175.

24. Lee HC, Jenner AM, Low CS, Lee YK: Effect of tea phenolics and their aromatic fecal bacterial metabolites on intestinal microbiota. Res Microbiol 2006, 157:876-884.

25. Bravo L: Polyphenols: chemistry, dietary sources, metabolism, and nutritional significance. Nutr Rev 1998, 56:317-333.

26. Jung CH, Kim JH, Park SJ, Kweon DH, Kim SH, Ko SG: Inhibitory effect of Agrimonia pilosa Ledeb. on inflammation by suppression of iNOS and ROS production. Immunol Invest 2010, 39:159-170.

27. Vogl S, Picker P, Mihaly-Bison J, Fakhrudin N, Atanasov AG, Heiss EH, Wawrosch C, Reznicek G, Dirsch VM, Saukel J, Kopp B: Ethnopharmacological in vitro studies on Austria's folk medicine - An unexplored lore in vitro anti-inflammatory activities of 71 Austrian traditional herbal drugs. J Ethnopharmacol 2013, 149:750-771.

28. Scapagnini G, Vasto S, Abraham NG, Caruso C, Zella D, Fabio G: Modulation of Nrf2/ARE pathway by food polyphenols: a nutritional neuroprotective strategy for cognitive and neurodegenerative disorders. Mol Neurobiol 2011, 44:192-201.

29. Mueller K, Blum NM, Mueller AS: Examination of the anit-inflammatory, antioxidant, and xenobiotic-inducing potential of broccoli extract and various essential oils during a mild DSS-induced colitis in rats. ISRN Gastroenterol 2013, 2013:710856.

30. Broussard SR, Zhou JH, Venters HD, Bluthé RM, Freund GG, Johnson RW, Dantzer R, Kelley KW: At the interface of environment-immune interactions: Cytokine and growth-factor receptors. J Anim Sci 2001, 79:E268-E284

31. Johnson RW: Inhibition of growth by pro-inflammatory cytokines: an integrated view. J Anim Sci 1997, 75:1244-1255.

32. Hougee S, Sanders A, Faber J, Graus YM, van den Berg WB, Garssen J, Smit $H F$, Hoijer MA: Decreased pro-inflammatory cytokine production by LPS-stimulated PBMC upon in vitro incubation with the flavonoids apigenin, luteolin or chrysin, due to selective elimination of monocytes/ macrophages. Biochem Pharmacol 2005, 69:241-248.

33. Nicholas C, Batra S, Vargo MA, Voss OH, Gavrilin MA, Wewers MD, Guttridge DC, Grotewold E, Doseff Al: Apigenin blocks lipopolysaccharide-induced lethality in vivo and proinflammatory cytokines expression by inactivating NF-kappaB through the suppression of p65 phosphorylation. J Immunol 2007, 179:7121-7127. 
34. Liang YC, Huang YT, Tsai SH, Lin-Shiau SY, Chen CF, Lin JK: Suppression of inducible cyclooxygenase and inducible nitric oxide synthase by apigenin and related flavonoids in mouse macrophages. Carcinogenesis 1999, 20:1945-1952.

35. Gesellschaft für Ernährungsphysiologie: Recommendations for energy and nutrients supply of pigs. 1. Auflage, Frankfurt am Main: DLG-Verlag; 2006.

36. Wang CC, Chu CY, Chu KO, Choy KW, Khaw KS, Rogers MS, Pang CP: Troloxequivalent antioxidant capacity assay versus oxygen radical absorbance capacity assay in plasma. Clin Chem 2004, 50:952-954.

37. Mueller K, Blum NM, Kluge H, Mueller AS: Influence of broccoli extract and various essential oils on performance and expression of xenobiotic- and antioxidant enzymes in broiler chickens. Br J Nutr 2012, 108:588-602.

38. Pfaffl MW: A new mathematical model for relative quantification in real-time RT-PCR. Nucleic Acids Res 2001, 29:e45.

doi:10.1186/s12917-014-0210-y

Cite this article as: Gräber et al: Studies on the health impact of

Agrimonia procera in piglets. BMC Veterinary Research 2014 10:210.

\section{Submit your next manuscript to BioMed Central and take full advantage of:}

- Convenient online submission

- Thorough peer review

- No space constraints or color figure charges

- Immediate publication on acceptance

- Inclusion in PubMed, CAS, Scopus and Google Scholar

- Research which is freely available for redistribution 